\title{
Total-Hg and organic-Hg in Cephalopholis fulva (Linnaeus, 1758) from inshore and offshore waters of NE Brazil
}

\author{
Lacerda, LD. ${ }^{\mathrm{a}, \mathrm{b} *}$, Santos, JA. ${ }^{\mathrm{a}}$, Campos, $R C .^{\mathrm{c}}$, Gonçalves, $R A .^{\mathrm{c}}$ and Salles, ${ }^{\mathrm{a}}{ }^{\mathrm{a}}$ \\ aLaboratório de Biogeoquímica Costeira, Instituto de Ciências do Mar, Universidade Federal do Ceará, \\ Av. Abolição 3207, Meireles, Fortaleza, CEP 60165-081, CE, Brazil \\ 'Departamento de Geoquímica, UFF, Niteroi, CEP 24020-007, RJ, Brazil \\ 'Laboratório de Absorção Atômica, PUC-RJ, \\ Rua Marquês de São Vicente, 225, Gávea, Rio de Janeiro, RJ, Brazil \\ *e-mail: pgcmt@labomar.ufc.br \\ Received October 26, 2005 - Accepted December 15, 2005 - Distributed August 31, 2007
}

(With 3 figures)

\begin{abstract}
To investigate whether source proximity or bioavailability is the major factor controlling both $\mathrm{Hg}$ concentration and $\mathrm{Hg}$ speciation in marine fishes, total- and organic- $\mathrm{Hg}$ content in muscle and liver tissues from different populations of Cephalopholis fulva (piraúna) from inshore and offshore waters of the Brazilian northeastern coast were analyzed. Average total-Hg in muscle (104 ng. $\mathrm{g}^{-1}$ w.w.) and liver $\left(2,865 \mathrm{ng} . \mathrm{g}^{-1}\right.$ w.w.) tissues, as well as organic-Hg concentrations in muscle (169 ng.g ${ }^{-1}$ w.w.) and liver (1,038 ng.g ${ }^{-1}$ w.w.), were much higher in the offshore population of $C$. fulva than in the inshore ones. In the inshore population total- $\mathrm{Hg}$ and organic- $\mathrm{Hg}$ average concentrations in muscle tissue were similar and reached only $49 \mathrm{ng} . \mathrm{g}^{-1}$ w.w., while in liver they reached $412 \mathrm{ng} . \mathrm{g}^{-1}$ w.w. for total-Hg and $180 \mathrm{ng}^{-\mathrm{g}^{-1}}$ w.w., for organic-Hg. Concentrations of both $\mathrm{Hg}$ species in the two populations were higher in liver than in muscle. The average percentage contribution of organic-Hg to the total $\mathrm{Hg}$ content was higher in muscle (98-100\%) than in liver (42-53\%), but similar between the two populations. Total-Hg and organic-Hg concentrations in muscle and liver from the offshore population showed significant $(\mathrm{P}<0.05)$ positive correlation with fish length. However, in the inshore population only the total-Hg and organic-Hg in muscle tissues correlate significantly with fish size. Although the coastal environments are enriched in total $\mathrm{Hg}$ relative to open waters, the significant higher $\mathrm{Hg}$ concentrations in the offshore population of C. fulv $a$ and the significant correlation found between organic-Hg in liver with fish size suggest higher bioavailability of $\mathrm{Hg}$ in offshore waters relative to inshore ones.
\end{abstract}

Keywords: total mercury, organic mercury, fish populations, Cephalopholis fulva, NE Brazil.

\section{Mercúrio total e mercúrio orgânico em Cephalopholis fulva (Linnaeus, 1758) em águas costeiras e mar aberto no nordeste do Brasil}

\begin{abstract}
Resumo
As concentrações de Hg-total e Hg-orgânico foram determinadas em diferentes populações de Cephalopholis ful$v a$ (piraúna) capturadas em águas costeiras e em bancos oceânicos do litoral nordeste do Brasil. A comparação entre as duas populações permitiu investigar o efeito da proximidade de fontes sobre as concentrações, e a especiação de $\mathrm{Hg}$ em músculo e fígado desta espécie. As concentrações médias de Hg-total em músculo (104 ng.g ${ }^{-1}$ w.w.) e fígado (2,865 ng.g $\mathrm{g}^{-1}$ w.w.), assim como as concentrações de $\mathrm{Hg}$-orgânico em músculo (169 ng.g ${ }^{-1}$ w.w.) e fígado (1,038 ng. $\mathrm{g}^{-1}$ w.w.) foram muito maiores na população capturada nos bancos oceânicos do que na população costeira. Nesta, as concentrações médias de Hg-total e Hg-orgânico na musculatura de C. fulva foram similares e baixas (49 ng. ${ }^{-1}$ w.w.), enquanto que atingiram 412 ng.g $\mathrm{g}^{-1}$ w.w. de Hg-total e 180 ng.g ${ }^{-1}$ w.w. de Hg-orgânico no fígado destes animais. As concentrações das duas espécies de $\mathrm{Hg}$ foram significativamente maiores no fígado do que na musculatura. A contribuição percentual média de Hg-orgânico para a concentração total de $\mathrm{Hg}$ nos peixes foi maior para músculo (98-100 \%) que para fígado (42-53 \%), mas semelhante entre as duas populações. As concentrações de Hg-total e Hg-orgânico na musculatura e no fígado de C. fulva mostraram-se positivamente correlacionadas com o tamanho do animal $(\mathrm{P}<0,05)$. Entretanto, na população costeira somente as concentrações destas espécies de $\mathrm{Hg}$ na musculatura apresentaram correlações significativas com o tamanho do animal. Embora o ambiente costeiro seja relativamente enriquecido em $\mathrm{Hg}$, em relação aos bancos oceânicos, as maiores concentrações de $\mathrm{Hg}$ foram verificadas na população oceânica de $C$. fulva. A correlação significativa entre Hg-orgânico no fígado e tamanho do animal no fígado sugerem uma maior biodisponibilidade do $\mathrm{Hg}$ em águas oceânicas quando comparada às águas costeiras.
\end{abstract}

Palavras-chave: mercúrio total, mercúrio orgânico, populações de peixes, Cephalopholis fulva, litoral nordeste. 


\section{Introduction}

Mercury levels in the aquatic biota respond to local bioavailability and vary among species of a given site and within a same species from different places. Also, $\mathrm{Hg}$ concentrations are different among different organs of a given species. For example, Storelli et al. (2005) measuring concentrations of total $\mathrm{Hg}$ and organic- $\mathrm{Hg}$ in the edible fish tissue from the Ionian and Adriatic seas, detected higher concentrations in striped mullet (Mullus barbatus), a benthic species, than in hake (Merluccius merluccius), a pelagic species. Romeo et al. (1999) evaluating $\mathrm{Hg}$ levels in muscle, gills and liver tissues in different fish species from the Mauritania coast, observed that $\mathrm{Hg}$ concentrations in the gills and muscle of the pelagic species are very low, whereas higher concentrations were found in the liver of benthic species. Joiris et al. (1999) determining total-Hg and organic-Hg in sardines from Tunisia found similar concentrations in the northern and eastern areas and significantly lower concentrations in the southern zone. Higher $\mathrm{Hg}$ concentrations occurred in the liver compared to muscle tissues regardless of the area sampled. In general, most previous studies have also shown a positive correlation between $\mathrm{Hg}$ concentration and fish length, suggesting biomagnification (Adams, 2004; Pinho et al., 2002; Joiris et al., 2000; Phillips et al., 1997).

Analyzing $\mathrm{Hg}$ speciation in muscle tissue of fish, numerous studies have demonstrated that most of the $\mathrm{Hg}$ present is bioaccumulated as metyl-Hg (Storelli et al., 2005), the most toxic form due to its neurotoxic properties (WHO, 1990). Anderson and Depledge (1997) reported percentages of organic-Hg varying from $63 \%$ and $86 \%$ of different fish species from Azorean waters. Joiris et al. (1999), analyzing muscle tissue of sardines from Tunisia, found that organic-Hg represents about $85 \%$ of the total $\mathrm{Hg}$ present in the fish muscle. Storelli et al. (2002; 2003) and Kehrig et al. (2005) found organic-Hg percentages varying from 75 to $100 \%$ and 94 to $100 \%$, in muscle tissue of tuna and other carnivorous fish species, respectively.

The spatial variability of $\mathrm{Hg}$ concentrations in populations of a single species has mostly been evaluated when comparing polluted and unpolluted sites. Less attention is given on the variability of $\mathrm{Hg}$ concentration and distribution in populations of a single species inhabiting different sites in a similar area, such as inshore and offshore waters of a given coast where, although under the influence of similar $\mathrm{Hg}$ sources, $\mathrm{Hg}$ may be present with different bioavailability to fish uptake.

The aim of this study was to analyze the total $\mathrm{Hg}$ and organic-Hg concentrations in the muscle and liver tissues of Cephalopholis fulva, a benthic grouper of significant economic importance, collected from inshore and offshore waters, free of any significant anthropogenic $\mathrm{Hg}$ source (Marins et al., 2004), on the Ceará coast in northeastern Brazil.

\section{Materials and Methods}

The red grouper Cephalopholis fulva (Linnaeus, 1758) occurs along the Western Atlantic from southern North Carolina and Bermuda to southeast Brazil, including the Bahamas and the continental and insular coasts of the Caribbean Sea, Fernando de Noronha Islands and Atol das Rocas atoll (Figueiredo and Menezes, 1980; Cervigón, 1991, Heemstra and Randall, 1993). The species is exclusively marine and inhabits coastal areas from up to $150 \mathrm{~m}$ deep, living close to coral reefs and rocky bottoms, in rifts and caves where it hides during the day. According to Cervigón (1991), it is found in up to $50 \mathrm{~m}$ depth, being more common in up to $25 \mathrm{~m}$. The alimentary diet of $C$. ful$v a$ consists of small fish and benthic invertebrate (Randall, 1967). This species doesn't present migratory habits, i.e. once a population settles it does not mix with others from different areas (Heemstra and Randall, 1993).

Specimens of C. fulva were caught in inshore waters in the Ceará continental shelf, NE Brazil and adjacent offshore oceanic waters (Figure 1). Both stations are located in front of the central portion of the Ceará coast receiving effluents from the most urbanized part of the coast and where major rivers are also located. The inshore population (11 individuals) was sampled at between 20 to $60 \mathrm{~m}$ deep by trawling the sandy coralline bottom of the continental shelf at about 20 nautical miles from the shore, whereas the offshore population (14 individuals) was sampled at the Mundau Oceanic Bank at $60 \mathrm{~m}$ deep, about 140 nautical miles from the shore. The Ceará Abyssal Plain of 3,500 m in depth extends between the two sites (MMA, 2004), representing an immense environmental barrier for demersal fish, guaranteeing that the two populations are specifically linked to their own substrate and habitat.

Fishes were brought to the laboratory where length, weight and sex were recorded. Soon after, samples were dissected to separate liver and muscle tissues and preserved at $-25^{\circ} \mathrm{C}$ until analysis. Total $\mathrm{Hg}$ and organic- $\mathrm{Hg}$ were determined by selective reduction after Magos (1971) and Limaverde Filho and Campos (1999). Samples of

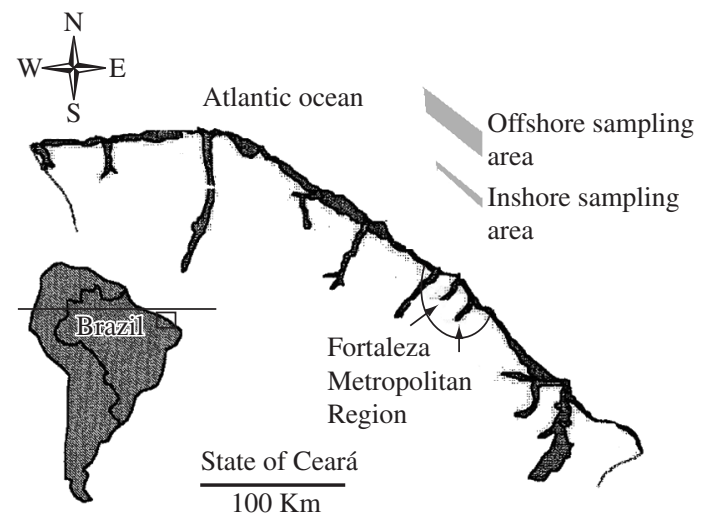

Figure 1. Map of the NE Brazilian coast where C. fulva were collected for $\mathrm{Hg}$ analysis. 
liver and muscle tissues ( $0.5 \mathrm{~g}$ wet weight) were digested with $4 \mathrm{~mL} 40 \% \mathrm{NaOH}$ and $1 \mathrm{~mL}$ of a $1 \%$ cystein solution in a heating plate at $70{ }^{\circ} \mathrm{C}$. Extracts, at room temperature, were taken to $10 \mathrm{~mL}$ with $1 \% \mathrm{NaCl}$. A $10 \mathrm{~mL}$ aliquot of the digested extract was treated with $1 \mathrm{~mL} 1 \% \mathrm{SnCl} /$ $\mathrm{CdCl}$ solution for the reduction of total $\mathrm{Hg}$ present in the sample. A second aliquot was treated with $1 \% \mathrm{SnCl}$ solution $(1 \mathrm{~mL})$, reducing only the inorganic $\mathrm{Hg}$ present. The organic-Hg fraction was estimated by the difference of the two reduction steps. Determination of $\mathrm{Hg}$ concentrations was performed with Cold Vapor Atomic Absorption Spectrophotometry (CVAAS) in a Varian model AA-6, equipped with a cold vapor generator.

The accuracy of total-Hg and organic-Hg determinations were tested by simultaneous analysis of Dogfish Muscle Certified Reference Material for Trace Metals - DORM-2, with average recovery of $96.1 \%$ for total-Hg and $98.0 \%$ for organic-Hg (Table 1). These results demonstrated accuracy and precision of the analytical method.

\section{Results and Discussion}

Table 2 gives fish length, total $\mathrm{Hg}$, organic- $\mathrm{Hg}$ and \% organic-Hg of the total $\mathrm{Hg}$ content in C. fulva. Average offshore fishes were larger $(313 \pm 43 \mathrm{~mm})$ than inshore fishes (263 $\pm 49 \mathrm{~mm})$. Total-Hg and organic-Hg concentrations

Table 1. Expected and measured $\mathrm{Hg}$ concentrations in the certified reference material DORM-2 (National Research Council of Canada), $(n=5)$.

\begin{tabular}{lcc}
\hline \multicolumn{1}{c}{$\mathrm{Hg}\left(\mu \mathrm{g} \cdot \mathrm{g}^{-1}\right)$} & $\begin{array}{c}\text { Certified } \\
\text { concentration }\end{array}$ & $\begin{array}{c}\text { Measured } \\
\text { concentration }\end{array}$ \\
\hline Total-Hg & $4.64 \pm 0.26$ & $4.46 \pm 0.03$ \\
Organic-Hg & $4.47 \pm 0.32$ & $4.38 \pm 0.03$ \\
(Methyl-Hg) & & \\
\hline
\end{tabular}

were much higherin liver than in the muscular tissue for both populations studied. In the offshore population, liver total$\mathrm{Hg}$ concentrations reached 2,865 $\pm 3,293 \mathrm{ng} \cdot \mathrm{g}^{-1}$ whereas in muscle, average concentrations reached $174 \pm 104 \mathrm{ng}$. $\mathrm{g}^{-1}$. Organic-Hg in this population reached 1,038 $\pm 1,031$ ng. $\mathrm{g}^{-1}$ in liver and $169 \pm 97 \mathrm{ng} . \mathrm{g}^{-1}$ in muscle. In the inshore population total-Hg concentrations in liver reached $412 \pm 406 \mathrm{ng} \cdot \mathrm{g}^{-1}$ whereas in muscle, average concentrations reached $49 \pm 28 \mathrm{ng} \cdot \mathrm{g}^{-1}$. Organic-Hg in the inshore population reached $180 \pm 154{\mathrm{ng} . \mathrm{g}^{-1}}^{-1}$ liver and $49 \pm 28 \mathrm{ng} \cdot \mathrm{g}^{-1}$ in muscle. The ratios between total $\mathrm{Hg}$ in liver to that of in muscle were 8.4 for the inshore population and 16.5 for offshore waters, much higher than most ratios reported in literature. For example, Joiris et al. (1999) found a ratio of 1.4 in Sardinella aurita and 1.7 for Sardina pilchardus sampled in Bangladeshi waters. In Cephalopholis nigri from Mauritania coast the ratio was 1.9 (Romeo et al., 1999). In carnivorous species sampled in SE Brazil, however, Kherig et al. (2005) found liver/ muscle ratios of $\mathrm{Hg}$ concentrations of 1.3 and of 12 for herbivorous species.

Total-Hg concentrations in the offshore population

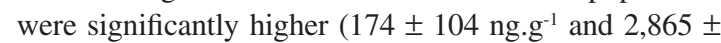
$\left.3,293 \mathrm{ng} \cdot \mathrm{g}^{-1}\right)$ in muscle and liver tissues respectively, than in inshore fishes $\left(49 \pm 28 \mathrm{ng} \cdot \mathrm{g}^{-1}\right.$ and $412 \pm 406 \mathrm{ng} \cdot \mathrm{g}^{-1}$, in muscle and liver tissues respectively). Similarly, organic$\mathrm{Hg}$ concentrations in the offshore population were also significantly higher (169 $\pm 97 \mathrm{ng} \cdot \mathrm{g}^{-1}$ and 1,038 $\left.\pm 1,031 \mathrm{ng} \cdot \mathrm{g}^{-1}\right)$ in muscle and liver tissues respectively, than in inshore fishes (49 \pm 28 ng.g ${ }^{-1}$ and $180 \pm 154$ ng.g ${ }^{-1}$ in muscle and liver tissues respectively). The percentage of organic- $\mathrm{Hg}$ to the total content was higher and constant in muscle, being $100 \%$ in the population of inshore waters and between 80 and $90 \%$ in the population of offshore waters. The organic-Hg fraction in liver of both populations was lower ranging from 42 to $53 \%$ in offshore and inshore fishes respectively. Similar distribution was found for Sardinella

Table 2. Fish length, total $\mathrm{Hg}$, organic- $\mathrm{Hg}$ and $\%$ of organic- $\mathrm{Hg}$ of the total $\mathrm{Hg}$ content in Cephalopholis fulva (Linnaeus, 1758), from two different populations sampled in inshore and offshore waters of the Ceará continental shelf, NE Brazil.

\begin{tabular}{|c|c|c|c|c|c|c|c|}
\hline $\begin{array}{c}\text { Fish } \\
\text { population }\end{array}$ & $\begin{array}{l}\text { Length } \\
(\mathrm{mm})\end{array}$ & $\begin{array}{c}\text { Total Hg } \\
\text { in muscle } \\
\text { (ng.g }{ }^{-1} \text { wet wt) }\end{array}$ & $\begin{array}{c}\text { Total Hg } \\
\text { in liver } \\
\text { (ng.g }{ }^{-1} \text { wet wt) }\end{array}$ & $\begin{array}{l}\text { Organic-Hg } \\
\text { in muscle } \\
\text { (ng.g }{ }^{-1} \text { wet wt) }\end{array}$ & $\begin{array}{l}\text { Organic-Hg } \\
\text { in liver } \\
\text { (ng. } \text { g }^{-1} \text { wet wt) }\end{array}$ & $\begin{array}{l}\text { Organic-Hg } \\
\text { in muscle }(\%)\end{array}$ & $\begin{array}{l}\text { Organic-Hg } \\
\text { in liver }(\%)\end{array}$ \\
\hline \multicolumn{8}{|l|}{ Inshore } \\
\hline Mean & 263 & 49 & 412 & 49 & 180 & 100 & 53 \\
\hline $\mathrm{SD}$ & 49 & 28 & 406 & 28 & 154 & 0 & 20 \\
\hline Minimum & 195 & 23 & 90 & 23 & 54 & 100 & 33 \\
\hline Maximum & 333 & 94 & 1,104 & 94 & 522 & 100 & 93 \\
\hline $\mathrm{n}$ & 11 & 11 & 11 & 11 & 11 & 11 & 11 \\
\hline \multicolumn{8}{|l|}{ Offshore } \\
\hline Mean & 313 & 174 & 2,865 & 169 & 1,038 & 98 & 42 \\
\hline $\mathrm{SD}$ & 43 & 104 & 3,293 & 97 & 1,031 & 5 & 12 \\
\hline Minimum & 260 & 31 & 238 & 31 & 146 & 80 & 29 \\
\hline Maximum & 380 & 425 & 10,190 & 425 & 3,048 & 100 & 62 \\
\hline $\mathrm{n}$ & 14 & 14 & 13 & 14 & 13 & 14 & 13 \\
\hline
\end{tabular}


aurita and Sardina pilchardus, with the organic-Hg fraction constant and high, from 85 to $97 \%$ in muscle tissue and only 20 to $50 \%$ in liver (Joiris et al., 1999) and for Micropogonias furnieri from SE Brazil, with 98 and $31 \%$ of organic-Hg in muscle and liver tissue respectively.
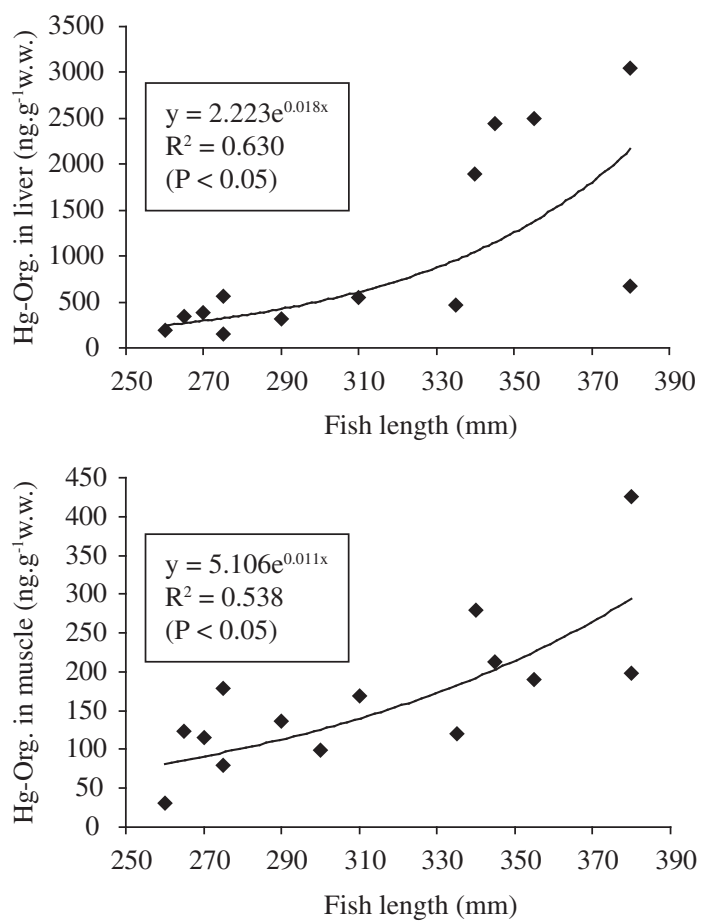

Total-Hg and organic-Hg concentrations in muscle and liver from the offshore population showed significant $(\mathrm{P}<0.05)$ positive correlation with fish length (Figures 2 and 3 ). However, in the inshore population only the total-Hg and organic-Hg in muscle tissues
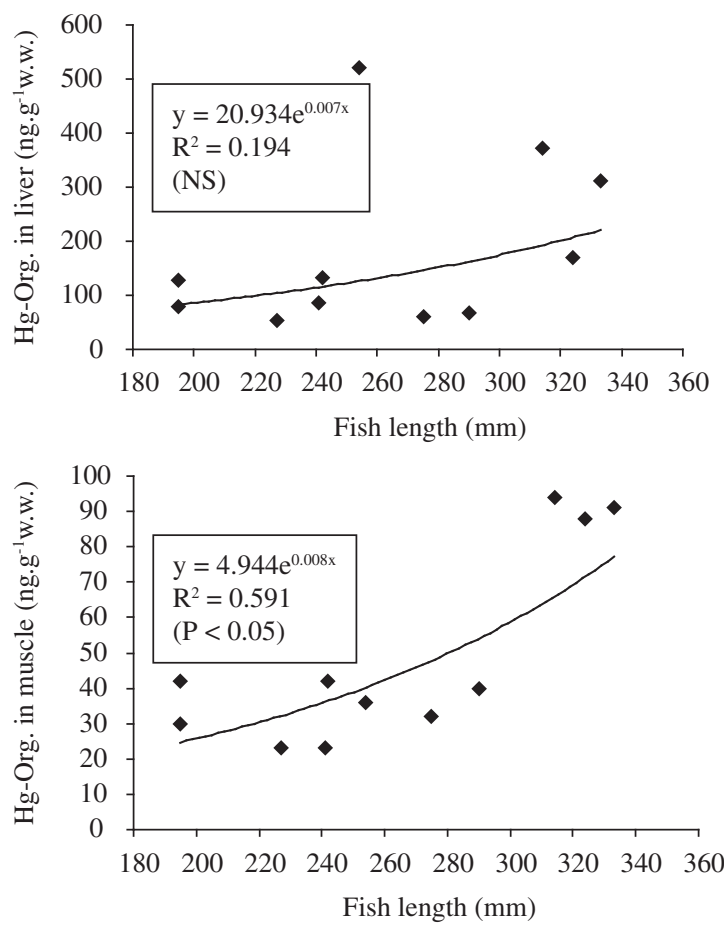

Figure 2. Correlation between organic-Hg concentrations and fish length in C. fulva from inshore (right) and offshore (left) waters of NE Brazil.
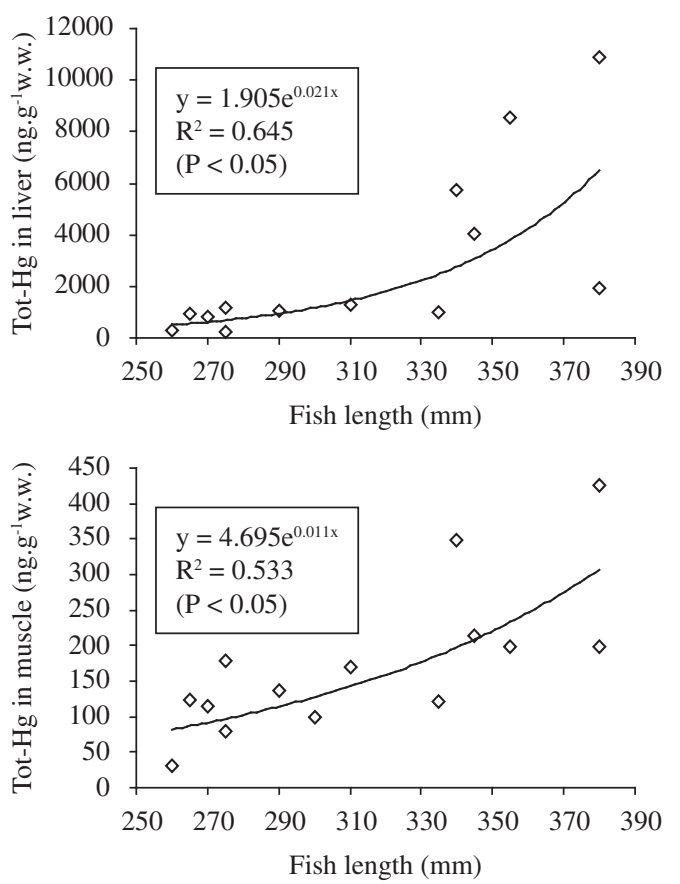
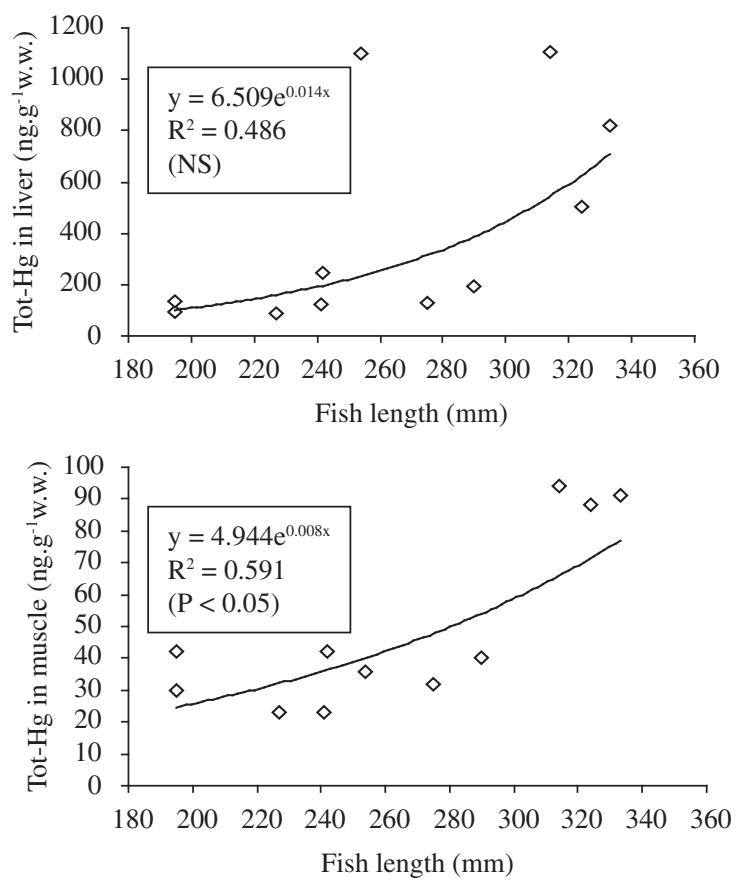

Figure 3. Correlation between total-Hg concentrations and fish length in C. fulva from inshore (right) and offshore (left) waters of NE Brazil. 
correlate significantly with fish size. The significantly higher $\mathrm{Hg}$ concentrations in the offshore population of C. fulva and the significant correlation found between organic- $\mathrm{Hg}$ in liver with fish size suggest intake of $\mathrm{Hg}$ from biological sources through the food web and therefore, is mostly organic $\mathrm{Hg}$ (Storelli et al., 2005; Adams, 2004; Pinho et al., 2002; Joiris et al., 1995). Also these different concentrations suggest higher bioavailability of $\mathrm{Hg}$ in offshore waters relative to inshore waters.

The difference in $\mathrm{Hg}$ concentrations between offshore and inshore populations can be explained by differences in size. From Figures 2 and 3 one can deduce that fish length could explain a twofold increase in concentrations at maximum and would hardly explain differences in liver concentrations. Difference in $\mathrm{Hg}$ availability between the two areas may contribute to a great extent to the difference. Various studies (Leermakers et al., 1995; Lacerda et al., 2001; Marins et al., 2002; Paraquetti et al., 2004) showed an increase in $\mathrm{Hg}$ reactivity in offshore waters in comparison with waters closer to the continent. In waters under the influence of continental inputs, $\mathrm{Hg}$ is mostly associated with clastic suspended matter (Lacerda and Gonçalves, 2001; Paraquetti et al., 2004). Ocean wards, $\mathrm{Hg}$ associated with dissolved organic matter increases, resulting in higher bioavailability (Paraqueti et al., 2004). On the Ceará coast, Marins et al. (2002) showed increasing dissolved $\mathrm{Hg}$ concentrations towards the ocean along estuarine and coastal waters. Similarly, on the SE Brazil continental platform, Lacerda et al. $(1993 ; 2004)$ showed that $\mathrm{Hg}$ could be transported from continental sources to deep offshore waters, being correlated to clastic material close to the shore and to organic complexes offshore. Therefore, offshore transport followed by increasing bioavailability could explain the differences in $\mathrm{Hg}$ concentrations between the two fish populations.

Acknowledgments - This study was supported by the Conselho Nacional de Desenvolvimento Científico e Tecnológico (CNPq), and the Fundação de Amparo a pesquisa do Estado do Rio de Janeiro (FAPERJ) through its PRONEX/FAPERJ Program project no. E26-171.175/2003.

\section{References}

ADAMS, DH. 2004. Total mercury levels in tunas from offshore waters of the Florida Atlantic coast. Mar. Pollut. Bull., vol. 49, no. $7 / 8$, p. 659-667.

ANDERSEN, JL. and DEPLEDGE, MH. 1997. A survey of total mercury and organicmercury in edible fish and invertebrates from Azorean waters. Mar. Environ. Res., vol. 44, no. 2, p. 331-350.

CERVIGÓN, F. 1991. Los peces marinos de Venezuela. vol. 1. Fundación Científica Los Roques, Caracas, Venezuela. 425 p.

FIGUEIREDO, JL. and MENEZES NA. 1980. Manual de peixes marinhos do sudeste do Brasil. III. Teleostei (2). Museu de Zoologia, Universidade de São Paulo. Brasil. 90 p.

HEEMSTRA, PC. and RANDALL, JE. 1993. FAO species catalogue. Groupers of the world. (Family Serranidae, Subfamily
Epinephelinae). An annotated and illustrated catalogue of the grouper, rockcod, hind, coral grouper and lyretail species known to date. FAO Fish. Synops. no. 125, vol. 16.

JOIRIS, CR., ALI, BI., HOLSBEEK, L., BOSSICART, M. and TAPIA, G. 1995. Total and organic mercury in Barents Sea pelagic fish. Bull. Environ. Contam. Toxicol., vol. 55, no. 5, p. 674-681.

JOIRIS, CR., HOLSBEEK, L. and MOATEMRI, NL. 1999. Total and Organicmercury in Sardines Sardinella aurita and Sardina pilchardus from Tunisia. Mar. Pollut. Bull., vol. 38, no. 3, p. $188-192$.

JOIRIS, CR., DAS, HK. and HOLSBEEK, L. 2000. Mercury accumulation and speciation in marine fish from Bangladesh. Mar. Pollut. Bull., vol. 40, no. 5, p. 454-457.

KEHRIG, HA., SEIXAS, TG., BAETA, A., LAISON-BRITO, J., MOREIRA, I. and MALM, O. 2005. Selenium, methylmercury and total mercury in different tissues offish and dolphins from a polluted tropical estuary. p. 385-388. In Proc. XIII International Conference on Heavy Metals in the Environment, CETEM, Rio de Janeiro,

LACERDA, LD., CARVALHO, CEV., REZENDE, CE. and PFEIFFER, WC. 1993> Mercury in sediments from the Paraíba do Sul River continental shelf, SE-Brazil. Mar. Pollut. Bull., vol. 27 , no. 6 , p. $220-222$.

LACERDA, LD. and GONÇALVES, GO. 2001. Mercury distribution and speciation in waters of the coastal lagoons of Rio de Janeiro, SE Brazil. Mar. Chem., vol. 76, no. 1, p. 47-58.

LACERDA, LD., REZENDE, CE., OVALLE, AR. and CARVALHO, CE. 2004. Mercury distribution in continental shelf sediments from two offshore oil fields in southeastern Brazil. Bull. Environ. Contam. Toxicol., vol. 72, no. 1, p. $178-185$.

LEERMAKERS, M., MEULEMAN, D. and BAEYENS, W. 1995. Mercury speciation in the Scheldt Estuary. Water Air Soil Pollut., vol. 80, no. 1/4, p. 641-652.

LIMAVERDE FILHO, AM. and CAMPOS, RC. 1999. Redução seletiva aplicada à especiação de mercúrio em peixes: uma adaptação do método de Magos. Química Nova, vol. 22, no. 4, p. $477-482$.

MAGOS, L. 1971. Selective atomic absorption determination of inorganic and methyl-Hg in undigested biological samples. Analyst, vol. 96, no. 6, p. 847-853.

MARINS,RV.,LACERDA,LD.,MOUNIER,S.,PARAQUETTI, HHM. and MARQUES, WS. 2002. Caracterização hidroquímica, distribuição e especiação de mercúrio nos estuários dos Rios Ceará e Pacotí, Região Metropolitana de Fortaleza, Ceará, Brasil. Geochimica Brasiliensis, vol. 16 no. 1, p. 37-48.

MARINS, RV., PAULA FILHO, FJ., LACERDA, LD., RODRIGUES, SR. and MARQUES, WS. 2004. Distribuição de mercúrio total como indicador de poluição urbana e industrial na costa brasileira. Química Nova, vol. 27, no. 5, p. 763-770.

MMA (MINISTÉRIO DO MEIO AMBIENTE), 2004, Características gerais da região de trabalho. http://www.mma. gov.br/port/sqa/projeto/revizee/caracter.html, [accessed in: december 10, 2004].

PARAQUETTI, HHM., AYRES, GA., MOLISANI, MM. and LACERDA, LD. 2004. Mercury distribution, speciation and flux in the Sepetiba Bay tributaries, SE Brazil. Wat. Res., vol. 38 , no. 6, p. 1439-1448. 
PHILLIPS, CR., HEILPRIN, DJ. and HART, MA. 1997. Mercury accumulation in Barred Sand Bass (Paralabrax nebulifer) near a large wastewater outfall in the Southern California Bight. Mar. Pollut. Bull., vol. 34, no. 2, p. 96-102.

PINHO, AP., GUIMARÃES, JRD., MARTINS, AS., COSTA, PAS., OLAVO, G. and VALENTIN, J. 2002. Total mercury in muscle tissue of five shark species from Brazilian offshore waters: effects of feeding habit, sex, and length. Environ. Res. Sect. A., vol. 89, no. 3, p. 250-258.

RANDALL, JE. 1967. Food habits of reef fishes of the West Indies. Stud. Trop. Oceanogr. Miami, no. 5, p. 665-847.

ROMEO, M., SIAU, Y., SIDOUMOU, Z. and GNASSIABARELLI, M. 1999. Heavy metal distribution in different fish species from the Mauritânia coast. Sci. Tot. Environ., vol. 232, no. 3, p. 169-175.
STORELLI, MM., GIACOMINELLI-STUFFLER, R. and MARCOTRIGIANO, GO. 2002. Total and organicmercury residues in tuna-fish from Mediterranean sea. Food Additives Contam. vol. 19, no. 6, p. 715-720.

STORELLI, MM., GIACOMINELLI-STUFFLER, R., STORELLI, A. and MARCOTRIGIANO, GO. 2003. Total and organicmercury content in edible fish from the Mediterranean Sea. J. Food Protect., vol. 66, no. 2, p. 300-303.

STORELLI, MM., STORELLI, A., GIACOMINELLISTUFFLER, R. and MARCOTRIGIANO, GO. 2005. Mercury speciation in the muscle of two commercially important fish, hake (Merluccius merluccius) and striped mullet (Mullus barbatus) from the Mediterranean sea: estimated weekly intake. Food Chem. vol. 89, no. 2, p. 295-300.

WHO. 1990. Organicmercury. In: Environmental Health Criteria. World Health Organization, Geneva. 